\title{
The Role of Ethical Leadership in Managing Occupational Stress to Promote Innovative Work Behaviour: A Cross-Cultural Management Perspective
}

\author{
Adnan ul Haque ${ }^{1(D)}$ and Fred A. Yamoah ${ }^{2, *(1)}$ \\ 1 Faculty of Business, Yorkville University, 2000 Steeles Avenue, Concord, ON L4K 4N1, Canada; \\ ahaque@yorkvilleu.ca \\ 2 Department of Management, Birkbeck-University of London, Malet St, London WC1E 7HX, UK \\ * Correspondence: f.yamoah@bbk.ac.uk
}

check for updates

Citation: Haque, A.u.; Yamoah, F.A. The Role of Ethical Leadership in Managing Occupational Stress to Promote Innovative Work Behaviour: A Cross-Cultural Management Perspective. Sustainability 2021, 13, 9608. https://doi.org/10.3390/ su13179608

Academic Editor:

Christian Vandenberghe

Received: 22 July 2021

Accepted: 24 August 2021

Published: 26 August 2021

Publisher's Note: MDPI stays neutral with regard to jurisdictional claims in published maps and institutional affiliations.

Copyright: (C) 2021 by the authors. Licensee MDPI, Basel, Switzerland. This article is an open access article distributed under the terms and conditions of the Creative Commons Attribution (CC BY) license (https:/ / creativecommons.org/licenses/by/ $4.0 /)$.

\begin{abstract}
This study examines the role of ethical leadership in managing occupational stress to engender innovative work behaviour (IWB) in cargo logistic SMEs in a contrasting cross-cultural management context of Canada and Pakistan. We draw on Trait Activation Theory to develop the conceptual and theoretical framework of the study. Using connections and a networking approach, a proportionate equal sample of nine SMEs were selected for the study. Analysis of the data from the semi-structured Skype and face-to-face interviews with 38 supervisors and 97 employees showed that ethical leadership plays a vital role in reducing occupational stress and increasing employees' IWB in both countries. Employees in both countries perceiving ethical leadership exhibit more creative-constructive behaviour. The results further demonstrate that males relative to females in both countries have a higher tendency of exhibiting risk-taking behaviour and IWB, resulting from leaders' support. Similarly, males have higher tendency of challenging the prevailing "status quo" within the organisations than females. Generally, the Pakistani workforce scored higher in contrast to the Canadian workforce in demonstrating IWB due to ethical leadership support, despite higher perception of occupational stress. Cross-cultural management implications are duly outlined.
\end{abstract}

Keywords: ethical leadership; innovative work behaviour; openness to experience; SMEs; Trait Activation Theory

\section{Introduction}

Consistently, organisations grapple with the serious challenge of survival in a highly fragile and dynamic business environment [1]. For this reason, many organisations resort to innovation when considering how to survive, succeed and progress in a such dynamic environment. "Innovative work behaviour" (IWB) is an essential element required by organisations to effectively and efficiently address various distinctive new challenges experienced as a result operating in a dynamic business environment [2]. IWB refers to is all employee behaviour that encourages, conceives, and executes unique and creative ideas [3]. Many studies consider IWB as a significant concept for adapting to the dynamic business environment and increasing the economic and financial performance challenges of organisations [4-6].

IWB is the most common intended behaviour in an organisation to have innovative employees to achieve organisational success within the context of intense competition. However, in addition to individual level, some researchers point out that IWB at the organisational level is also referred to as the collective level behaviour [7-9]. The aforementioned studies also reported a significant linkage between IWB and various attributes such as personality, leadership, work environment, and individual values.

Anxiety and depression are frequently visible at workplace [10]. However, occupational stress is one constant phenomenon that could not be separated from the life of the 
professionals [11-15]. For this reason, in the present study, the focus is to explore the impact of personality trait (ethical leadership) on IWB in the presence of occupational stress. Further, the reason for opting for a qualitative perspective is because our research aims at adopting the nature of flexibility and specificity instead of standardization and generalizability [16]. The aim is to explore the hidden embedded nuanced links so as to unearth in-depth insight and understanding rather than factual truth (mathematical objectivity) [17]. This current study thus departs from existing studies that only focused on individual innovation from a quantitative perspective $[9,18]$. We further contribute to existing studies that have examined the association between individual innovation and particular types of personality traits [19-21].

Occupational stress is considered as the disturbance of body's natural equilibrium [11-14]. Moreover, [15] argued that employees having higher tendency to demonstrate stressful situations at workplace. Thus, occupational stress could consistently affect the implementation of new ideas and perhaps escalate to affect IWB. Thus, we examined the relationship between occupational stress and IWB from a qualitative research perspective. Specifically, we investigated the role of ethical leadership (contextual factor) in strengthening or weakening the relationship between the variables of interest (occupational stress and IWB). The authors of [22] explored a similar relationship between openness to experience and IWB using ethical leadership through quantitative methods. The present study extends [22] by qualitatively exploring the phenomenon of occupational stress in relation to IWB within the context of ethical leadership.

The reason for considering a contextual variable as a main marginal condition is based on research evidence that employees' behaviour is significantly affected by the context $[23,24]$. Additionally, some studies $[25,26]$ have demonstrated that the behavioural expression of different types of personality traits depend on a particular situational context. Furthermore, [27] argued that a certain type of personality traits is activated by employees due to the context, which work as a motivator or a trigger for them to act in a particular way or the other. Since we considered IWB at the organisational level in addition to the individual level, the concept of leadership support is also included as a contextual factor that, along with innovation in organisations [28-31] and occupational stress perhaps, could affect IWB. Further, we investigate the leadership role as a contextual factor.

According to [32], ethical leadership is "the demonstration of normatively appropriate conduct through personal actions and interpersonal relationships, and the promotion of such conduct to follower through two-way communication, reinforcement, and decisionmaking". Moreover, ref. [33] argued that autonomy enhancement and rewards as means for encouraging ethical behaviour is common feature under ethical leadership. Interestingly, leaders exhibiting ethical style show higher concern for others and accept the mistakes of the employees rather than blaming and punishing others [32]. Furthermore, employees' behaviour receives guidance and important signals through this style of leadership [34]. Hence, ethical leadership facilitates as a support function in enhancing employees' positive experiences, forming new methods of working patterns, and importantly bringing improvement in the procedures of performing distinctive activities [35].

Despite having a plethora of research about leadership, innovative work behaviour, and occupational stress, there is no conclusive evidence from examining the three different constructs explored together through the lens of Trait Activation Theory. This is the existing gap in the literature that provides the foundation to enhance the body of knowledge by providing a more in-depth understanding of this research phenomenon. Considering the existing literature, we found limited research exists on the impact of personality trait (ethical leadership) on IWB in the presence of occupational stress. This is the stand-out feature of the current paper. Furthermore, the existing literature is overly one-sided, using quantitative methods. This study is significant in providing the new balance by offering the insight into this research phenomenon through qualitative perspective. There is the need to shift the methodological paradigm and this study fills the gap by covering the missing qualitative approach. In other words, this study makes a methodological 
contribution by providing qualitative understanding in addition to the mathematically approached to study this phenomenon. The study extends knowledge and applicability of Trait Activation Theory by showing that ethical leadership play a vital role in reducing occupational stress and increasing employees' IWB in both countries. Thus, previous studies were limited to single economies while we considered comparative study in two economies for expanded insights. We further contribute to IWB literature by revealing that employees in both countries who are influenced by perceived ethical leadership exhibit more creative-constructive behaviour. This indicates that we delimit the existing approach by contributing to the new literature from a cross-cultural lens. Gender-related studies also benefit from the present study as no prior studies have researched the role of gender on the similar topic in the comparative context of emerging versus advanced economies (Canada and Pakistan). There is a gap in the existing literature as to whether any specific gender has higher/lower or similar/different tendencies to challenge the status quo. This scope of this study expands research insight by including the presence of occupational stress to understand IWB demonstration due to ethical leadership in distinctive economies.

In this study, we adopt the Trait Activation Theory of [36] for examining the moderating role offered by ethical leadership in occupational stress management and IWB relationship. The theory argues that in a certain supportive context, an employee tends to show particular personality traits. Hence, by means of ensuring effective occupational stress, management might advance or restrict IWB in the presence of ethical leadership in an organisational setting. This research addressed two main objectives. Firstly, it contributes towards expanding the frontiers of knowledge by examining the IWB and personality relationship through impact of occupational stress on IWB. Secondly, it provides a novel understanding of the relationship between occupational stress and IWB explored through ethical leadership's moderating role in the relationship. To achieve this aim, we conducted in-depth, semi-structured interviews with 38 logistics firm supervisors (23 in Canada, 15 in Pakistan) and 97 employees (58 in Canada, 39 in Pakistan). Thus, focusing on the two countries provides a cross-cultural management context to examine the role of ethical leadership in the relationship between occupational stress management and IWB. Hence, it offers a broader scope to understanding the phenomenon in depth. In other words, this study is unique and significant for more than one reason.

This paper is divided into four sections. In Section 1, we focus on the literature review that raises the conceptual understanding of innovative work behaviour (IWB) and occupational stress, and the moderating role of ethical leadership with IWB. In Section 2, we give detailed information regarding the research method. In Section 3, we demonstrate the findings and discussions, and then we conclude the paper.

\section{Literature Review}

Employees face ethical dilemmas, various conflicts, and many other types of risks when they demonstrate IWB [37]. Thus, ethical leadership support is a vital requirement for employees as they largely emphasize social responsibility, autonomy, and mortality. The authors of [38] indicated that a higher level of concern for employees is a visible aspect of ethical leadership. Moreover, an ethical leadership attribute includes mainly the openness of a leader to accept mistakes of employees and form interpersonal relationships [39,40].

The authors of [37] further argued that under strong ethical leadership, organisational innovation is enhanced as employees demonstrate creative behaviour, generate new ideas, and willingly take risk to use new approaches for resolving problems due to a culture of innovative environment. However, under a weak ethical leadership style, the employees are unable to come up with new ideas and thus continue displaying routine behaviour that also reduces IWB within the organisation. Hence, in situations where ethical leaders demonstrate a higher ethical role, the employees will have higher perceived support from their respective leaders. Interestingly, there is no conclusive evidence if occupational stress is reduced or increased under ethical leadership. 


\subsection{Innovative Work Behaviour (IWB) and Occupational Stress}

According to [41], individuals having the traits of "openness to experience" would be able to demonstrate and implement "innovative work behaviour" (IWB) at workplace. However, occupational stress exists within the organisation, and it can affect the performance of the employees in positive as well as negative manner $[10,14]$. Numerous studies have demonstrated that stress could be positive as well as negative $[11,12,42,43]$. However, there is no study at hand that connects the relationship between IWB and occupational stress in a direct manner. There are some indirect attempts through job demands and so on, but those did not specifically examine stress and IWB. Few studies found that individuals with an "open mind" tend to generate and implement unique and innovative ideas and solutions, contributing towards IWB [3,44]. In addition, [45] argued that a higher degree of innovative thinking results from a healthy curiosity, as it is the common feature of openminded individuals. Due to this, such individuals generate various unique perspectives and ideas $[45,46]$.

As per [14], occupational stress affects work, the worker, and workplace while the external CSR and social support help in improving performance. This indirectly points towards ethical leadership when discussing the CSR and social support from managers at workplaces. Good performance will be highly visible among individuals having higher curiosity, imagination, a broad mind, and an original thought processing style $[47,48]$ when stress is manageable [14,41,42].

Haque [14] argued that depression, anxiety, emotional imbalance, and serious behavioural problems are some of the other words to describe occupational stress. Moreover, ref. [14] argued that a little stress is a good thing (eustress) and could lead to creativity and innovation. The authors of [13] stated that individuals relying heavily on their internal sensations are highly intellectually challenged thus exhibiting higher eustress (occupational stress). This evidence shows that eustress (occupational stress) is a significant variable for predicting IWB because individuals having manageable occupational stress demonstrate innovative behaviour due to diverse experience at workplace $[11,13,14]$.

\subsection{Moderating Role of Ethical Leadership with Innovative Work Behaviour (IWB)}

IWB results from the "openness-to-experience" traits when employees are willing to show the wide range of their ideas, perspectives, feelings, and imaginations [20]. Interestingly, it can be inferred from [14] that innovation propensity (creativity) is predicted to some extent by the eustress (occupational stress). Furthermore, leadership support is a vital aspect for employees to be more innovative and productive because new ideas emerge when workers are relaxed [49,50]. In other words, employees tend to exhibit higher innovation and creativity when they feel comfortable. Therefore, leadership support plays an important role in enlightening employees' creativity and innovation. However, ref. [51] stated that natural leaders behave and act differently as per the requirement of the situation and hence, this sometimes poses a challenge for leaders and employees to work effectively in a consistent manner all the time. The authors of [52] also argued that in such situations where a conflict of interest arises, the authority of the employees is challenged, and this precipitates a higher risk in developing new innovative ideas. Hence, leaders' support and normative guidance enables employees in exhibiting innovative work behaviour in an organisational setting $[9,53]$.

Ethical leaders have relatively higher focus on the autonomy of employees and fairness of operations [38]. For this reason, useful, new, and innovative ideas result when employees are encouraged to take risk as part of support from the ethical leaders [22]. This situation demonstrates that perceived and received support from the ethical leaders enables employees to create innovative ideas and solutions by reducing stress or formulating eustress (good stress), leading to effective "innovative work behaviour".

Considering Trait Activation (CTA) Theory, one can argue that the employees having the openness-to-experience personality trait, especially when the employees perceive ethical support of leaders, demonstrate higher effective IWB. However, the indirect notion 
is driven from the work of [14] that creativity results from ethical leadership's social support, and that a little stress (eustress) is constructive.

Additionally, the CTA theory also suggests that through occasions or trait-related cues, the personal human behaviour disposition consequences enhance due to trait-relevant situational factors $[26,36]$. Furthermore, it leads to a situation where the individual could respond consistently or inconsistently with their inherent traits (ibid). The authors of [32] argued that altruism, integrity, and honesty are key features of ethical leadership. Moreover, a desirable attitude of employees tending to show eustress requires encouragement by ethical leadership characteristics in order to exhibit IWB [54]. However, ref. [55] argued that content and pleasure experienced by employees enable them in expressing their traits. Thus, higher IWB is exhibited by employees who are able to manage occupational stress. However, there is no conclusive information existing on whether stress could be wellmanaged under the ethical leadership's wing. IWB of employees results from the ethical leaders' support because it helps employees in demonstrating new ideas. Hence, the positive perception of employees such as viewing their leader as ethical is constructive in exhibiting IWB. Conversely, if employees view or perceive their leader as unethical, it will restrict them from being creative and innovative in the implementation of new ideas $[9,37]$.

Interestingly, the responsible leadership affecting organisational commitment is examined through Social Identity Theory (SITL) for assessing the value-based leadership [56]. The same study concluded that organisational commitment is significantly affected by the value-based (responsible) leadership. On the other hand, Javed et al. [57] found that ethical leadership supports IWB and creativity using Trait Activation Theory. Nonetheless, it fails to consider the occupational stress as an established phenomenon that could have an impact on IWB. Notwithstanding this limitation, the work of Javed et al. [57] is significant in hinting towards value added by the leadership. The work of Anser et al. [58] investigated the relationship between ethical leadership and knowledge-hiding behaviour and confirmed that role of leadership cannot be discarded from reducing knowledge-hiding behaviour. Critical review of the literature revealed that Saleem et al. [59] used social learning theory to conclude that ethical leadership impacts employees' green behaviour through mediation of green psychological climate. However, the considered theory contributes to value-added leadership, but fails to examine the relationship in the presence of occupational stress. The work of Usmanova et al. [60] explored the supportive role of colleagues, IWB, creative self-efficacy due to motivating language of leaders. The study found motivating language has a positive relationship with IWB when creative self-efficacy is mediator but not as a moderator. This is interesting, but again, occupational stress was not covered, which is a gap in the existing work. Thus, this study is built on the argument that in the presence of occupational stress, further study is warranted to better understand IWB. The work of Haque [61] found a significant direct impact of SHRM on employee turnover intentions and perceived organisational performance. Nonetheless, the work of Haque did not consider occupational stress of employees, which could affect the perceived organisational performance. Different studies use different theories to investigate the distinctive aspects of organisational behaviour, including innovative work behaviour. The current study, therefore, relied on axiological stance to justify its selection and use as a framework underpinning the research. Thus, the choice of activation theory offers a new but complementary pathway that provides a higher openness to engage the subject matter.

\section{Research Methodology}

In this cross-sectional comparative study, data were collected from selected logistic firms in Canada and Pakistan. These two countries were chosen for a cross-cultural comparative study because both countries are highly distinct based on the five cultural dimensions coined by Hofstede-individualism, power distance, uncertainty avoidance, masculinity, and long-term orientation $[62,63]$. Nonetheless, the two considered countries have similar trends and variations in the logistic businesses [11-14,17]. We aimed to examine the advanced and emerging economies in terms of trends and variation in contrasting 
economies, and two options that emerged were "UK and Pakistan" and "Canada and Pakistan" [11-14,17,44,57]. Nonetheless, considering specifically logistic businesses [17,44,57], we found similar trends and thus, we considered Pakistan and Canada. The rationale of selecting two contrasting economies (comparative case) instead of a single case study is due to the aspect of generalizability. A single case study is region-specific while comparative economies delimit specificity by offering greater generalizability $[12,14,17]$. Thus, the study presents a cross-cultural management research insight with practical implications for logistics organisations working in these countries. Using networking and professional connections, the researchers approached 25 SMEs in Canada, and nine, reflecting a 36\% response rate, agreed, and participated in the study. On the other hand, the first nine SMEs that were approached in Pakistan agreed to participate in the study, giving the research team an equal number of organisations from both countries to be included in this study. After the formal consent attained from the HR department of the selected organisations, researchers requested HR officers for the arrangement of Skype/face-to-face interviews with the supervisors and employees. In Canada, interviews were first conducted with the employees, followed by their supervisors. A similar pattern was followed in Pakistan. The Canadian sample consisted of 23 supervisors while the Pakistani sample had 15 supervisors out of the 65 total approached (collective response rate of $58.46 \%$ ), as well as 58 employees in Canada and 39 from Pakistan (total 97 out of total 200 approached, reflecting a 48.5\% collective response rate). Hence, 38 supervisors and 97 employees participated in this study. The sampling sizes in the qualitative studies are not determined like quantitative studies; the rule of thumb is to have a sufficient sample size is for quantitative studies, whereas theoretical saturation is used in qualitative studies [12-14,17]. Additionally, ref. [64] argued that between 30-50 interviews are effective in reaching saturation point in comparative studies. A saturation point is when there is no new or different response incurring [14]. Thus, saturation point attained in this study with 38 interviews with the supervisors and 97 employees.

The rationale behind qualitative studies is that the emphasis remained on the exploring research phenomenon. The hidden embedded themes are explored so that the useful truth could be attained. The human feelings and opinions, if numerically expressed, do not mean that they convey the underline hidden themes [17]. The mathematical objectivity could be attained, but how the truth could be useful would remain questionable. The over reliance on quantitative methods is one of the subjective approaches often practiced in academic research. The use of a qualitative method itself is the evidence that not each and every thing could be or should be quantified. The grounded theory is widely acceptable, as opposed to a positivist approach, which may not be appropriate in all situations. Hence, we argue that a qualitative approach is equally as prudent as quantitative methods.

The first set of questions related to "ethical leadership" and "occupational stress", and these featured in the interviews with the employees, whereas participating supervisors were asked about the "IWB" of participating employees. Every employee was coded by his/her respective employment ID and supervisors of their respective department were coded to ensure that every supervisor expressed views about his/her own subordinates. The study used existing scales for measuring the stress in the workplace adopted from earlier studies, including $[10,11,14]$. They include, "How often do you feel stress due to workload", "define yourself at the stressful situation", "How do you feel when you are given orders on short deadline?", "Do you think you are able to finish assigned task in the right manner, even when you are stressed?", and "Are you interested in abstract ideas and creative thoughts?" Moreover, items on instruments for measuring ethical leadership by [32] was considered in this study. These items included, "Do your supervisor makes fair and balanced decisions?", "How does your supervisor define success, is it by the means or ends?", and "Do you think your supervisor listens to what employees have to say?". Additionally, the study adopted the tenitem scale of De Jong and Den Hartog [30] for asking supervisor's views regarding the IWB of employees. Items included, "How often does this employee, pay attention to issues that are not part of his daily work?", "How often does this employee, generate original solutions for problems?", 
"How often does this employee, attempt to convince people to support an innovative idea?", and "How often does this employee, put effort in the development of new things?".

Further, the study followed the pattern of using age, gender, and experience as controlled variables as explored in earlier studies (see $[65,66])$. For reliability and validity purposes, the backgrounds of the participants were checked with HR officers by asking them to confirm the age, education, experience, etc., of the randomly picked employees by giving them their employment ID numbers. The formal email explained that the research objective is academic, and participants' anonymity and confidentiality was assured. Unlike in quantitative methods, the common method bias is not determined through statistical tests. Instead, the validity and reliability of the construct, content, and fair representation method is employed in qualitative studies to overcome the issue of common method bias $[12,14]$. In this research, we employed the similar technique used by previous studies $($ see $[12,14])$ to ensure the fairness of the process. In both countries, interviews were conducted in the English language. Researchers used coding, labelling, and thematic analysis to determine frequencies, and later, proportional analysis.

\section{Findings and Discussions}

As evident in Table 1, the majority of the employees were male $(61.2 \%)$, having a bachelor's degree $(42 \%)$, with average of $5-7$ years of working experience $(39 \%)$, and aged between 35 and 42 years (37.2\%).

Table 1. Demographic variables—employees' representation.

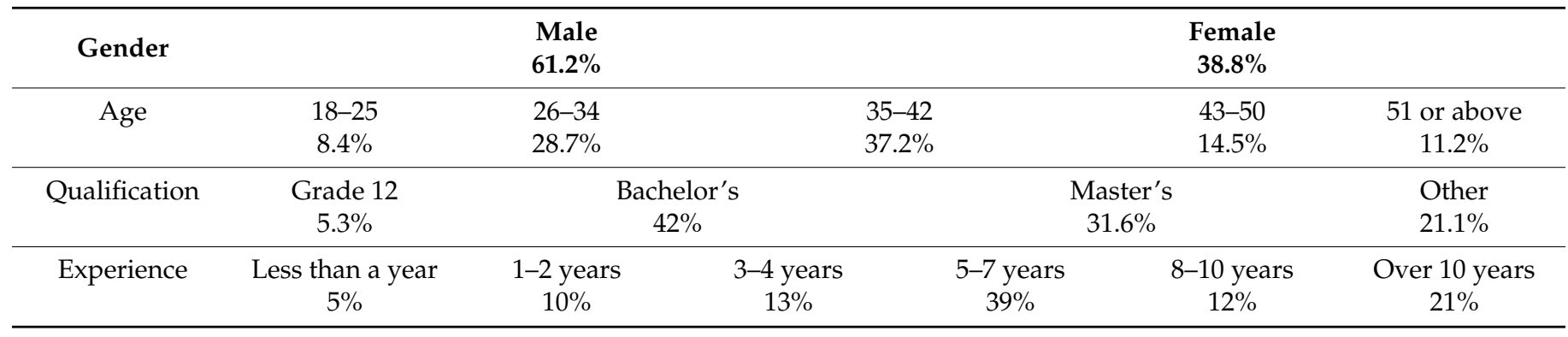

On the other hand, the majority of the supervisors were male $(73.2 \%)$, having a master's qualification (53.2\%), aged between 45 and 54 years (46.3\%), and with an average of 7-10 years' experience (31.2\%) (Table 2).

Table 2. Demographic variables—supervisors' representation.

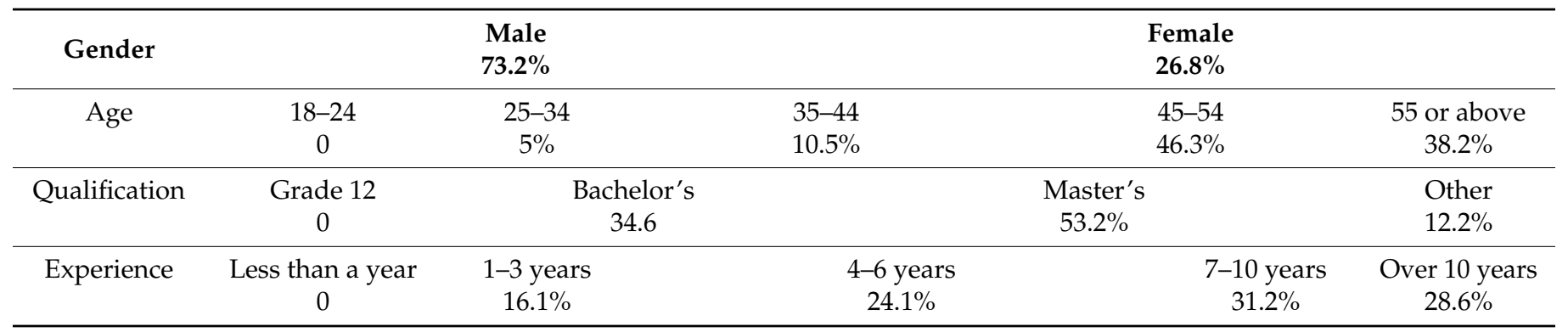

Through funnel approach, it is evident that Canadian supervisors are more experienced in contrast to Pakistani supervisors (67.2\% against 55.2\%; Figure 1). Moreover, the workforce in Pakistan is relatively young and less experienced in contrast to the Canadian workforce $(72.1 \%$ against $36.5 \%$, Figure 1$)$. In term of gender comparison, the Canadian workforce has a higher number of males, whereas a higher number of females constitute the Pakistani workforce $(66.7 \%$ against $57.2 \%$, Figure 1$)$. Interestingly, on the average supervisors with minimum three subordinates were considered in this study. 


\section{Comparison of attributes in contrasting economies}

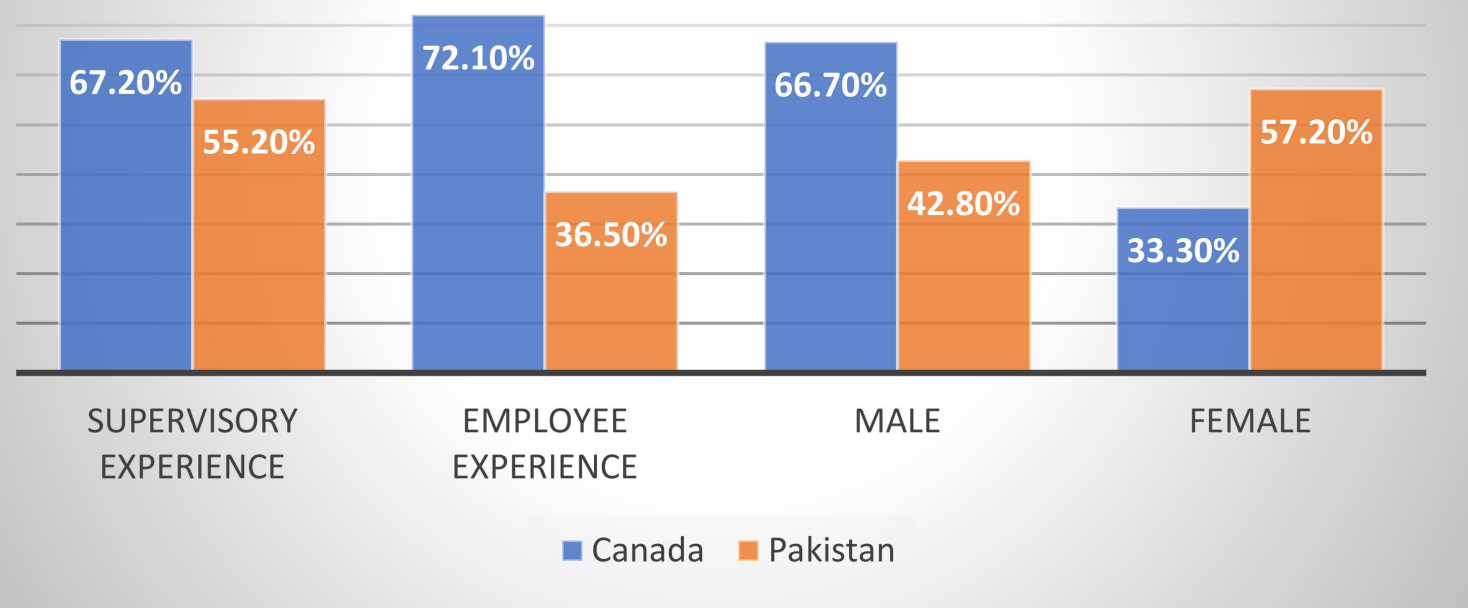

Figure 1. Different attributes in the contrasting economies (funnel approach).

Proportional analysis revealed that overall, 72\% of employees exhibited IWB (Table 3; Figure 2). Some of the responses are shown below.

Table 3. Employees exhibiting innovative work behaviour (IWB).

\begin{tabular}{ccc}
\hline Yes & Unsure & No \\
\hline 70 & 9 & 18 \\
\hline
\end{tabular}

\section{EMPLOYEES EXHIBITING IWB}

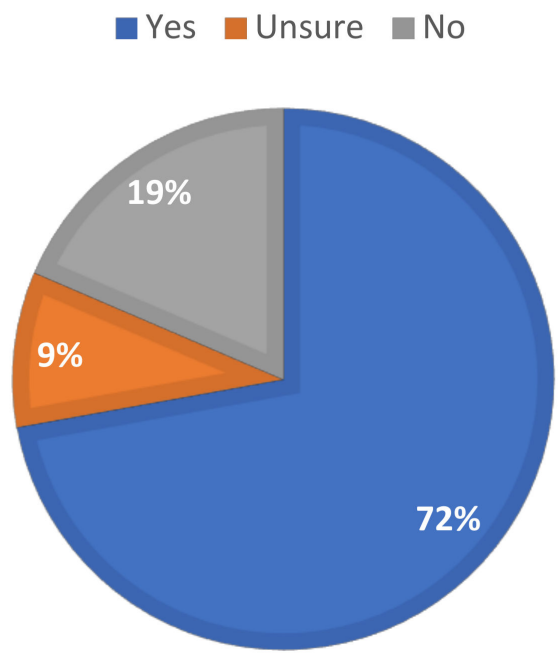

Figure 2. Own illustration of employees demonstrating IWB. 
The analysis revealed that participants show IBW by being more creative and taking self-initiative (Table 4).

Table 4. Responses from participants reflecting IWB.

I always look for new plans on daily basis.
Yes, at work I want to try experimenting new things

In addition to that, the Pakistani workforce showed higher IWB in comparison to the Canadian workforce.

The comparison is reflected through the inclusion of responses from both economies in Figure 3 and Table 5.

\section{Comparison of country context exhibiting IWB}

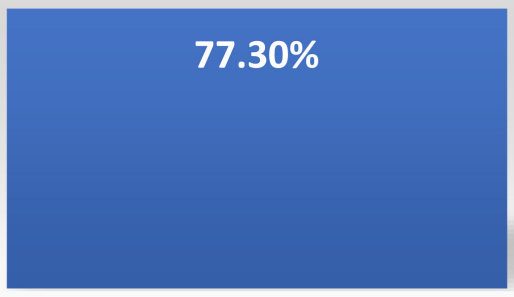

Pakistan

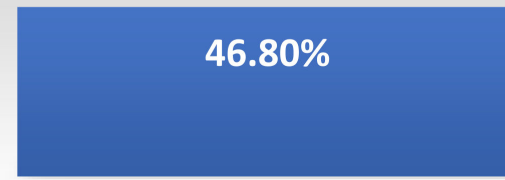

Canada

Figure 3. Comparison of country context exhibiting IWB.

Table 5. Innovative work behaviour (IWB)-related responses from contrasting economies.

Canadian respondent $\begin{array}{r}\text { Response 1: Thinking different gives me a spark at work } \\ \text { Response 2: I try usually doing extra than required just to improve myself }\end{array}$
Response 1: This work has really challenged me and I feel every time I
learn new thing
Pakistani respondent
Response 2: My learning curve continuously improves because of the
creative work
Response 3: Yes, indeed I feel I am learning new things every time

The analysis also considered three-item measurement by considering ethical leadership, occupational stress, and IWB under proportional analysis while comparing and exploring two dimensions, namely gender and economies.

Firstly, the majority of participants confirmed the negative relationship between occupational stress and IWB (81.2\% against 9.7\%, Figure 4). Moreover, the majority confirmed that IWB is not predicted by occupational stress (69.2\% against $14.3 \%$, Figure 4$)$. Further evidence is presented in Table 6.

Interestingly, higher ethical leadership perceived by employees showed lower occupational stress and higher IWB (55.6\% against 23.4\%, Figure 5 and Table 7). 


\section{Occupational stress \& IWB}

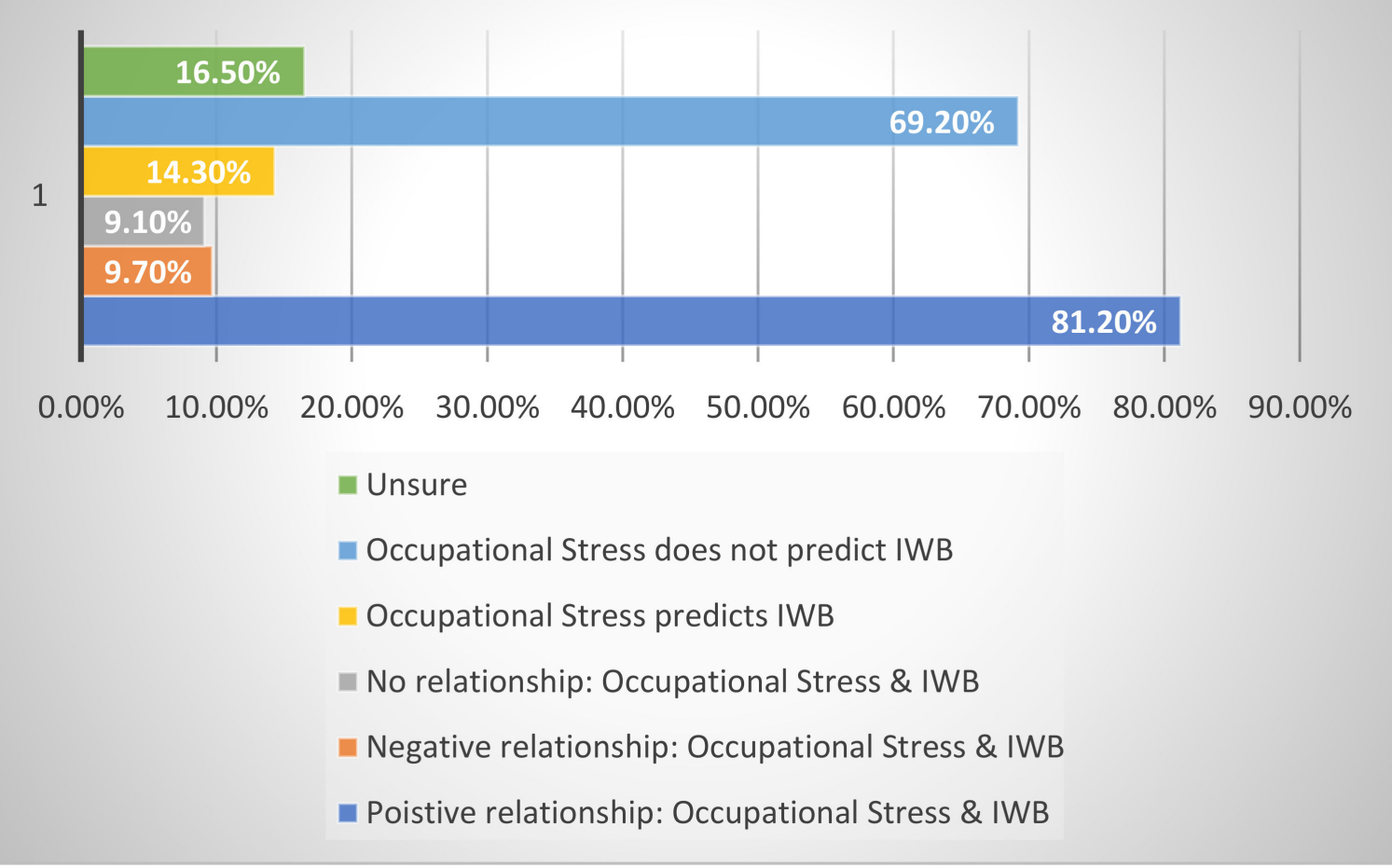

Figure 4. Occupational stress and IWB.

Table 6. Occupational stress and IWB.

Negative relationship between occupational stress and IWB

$\begin{array}{r}\text { am shy to express myself. } \\ \text { Occupational stress does not predict IWB } \quad \begin{array}{r}\text { Response 1: Not at all, when I am stressed, I cannot show } \\ \text { my innovation. } \\ \text { Response 2: Of course not, more I am stressed for any } \\ \text { reason, the lesser innovative thinking I will show. }\end{array} \\ \hline\end{array}$

Table 7. Perceiving ethical leadership reduces stress and improves IWB.

Well, yes I learn new things when I try. How can the manager expect me to do good when I am fearing everything and depending on him? When I see my manager is setting good examples I am more keen to perform well. When manager shouts or say something that stresses employee, they are nervous. In my case, my manager is very consideration and I can share anything with him. He helps me a lot at work in reducing my stress, this is the reason I do well.

See it is like confidence building. There is direct connection. I am given chance to work out my own way then I will bring new ideas. The more you force me to move in your given direction the less I will use my brain. In case of manager, I do trust his decision. He makes balance decisions and gives me full free hand so I am open to try new things. He unburden my stress so I feel less stressed because of good behaviour of my manager and it automatically improves my functionality and creativity. 


\section{Peceiving Ethical leadership - reduce stress+increase IWB}

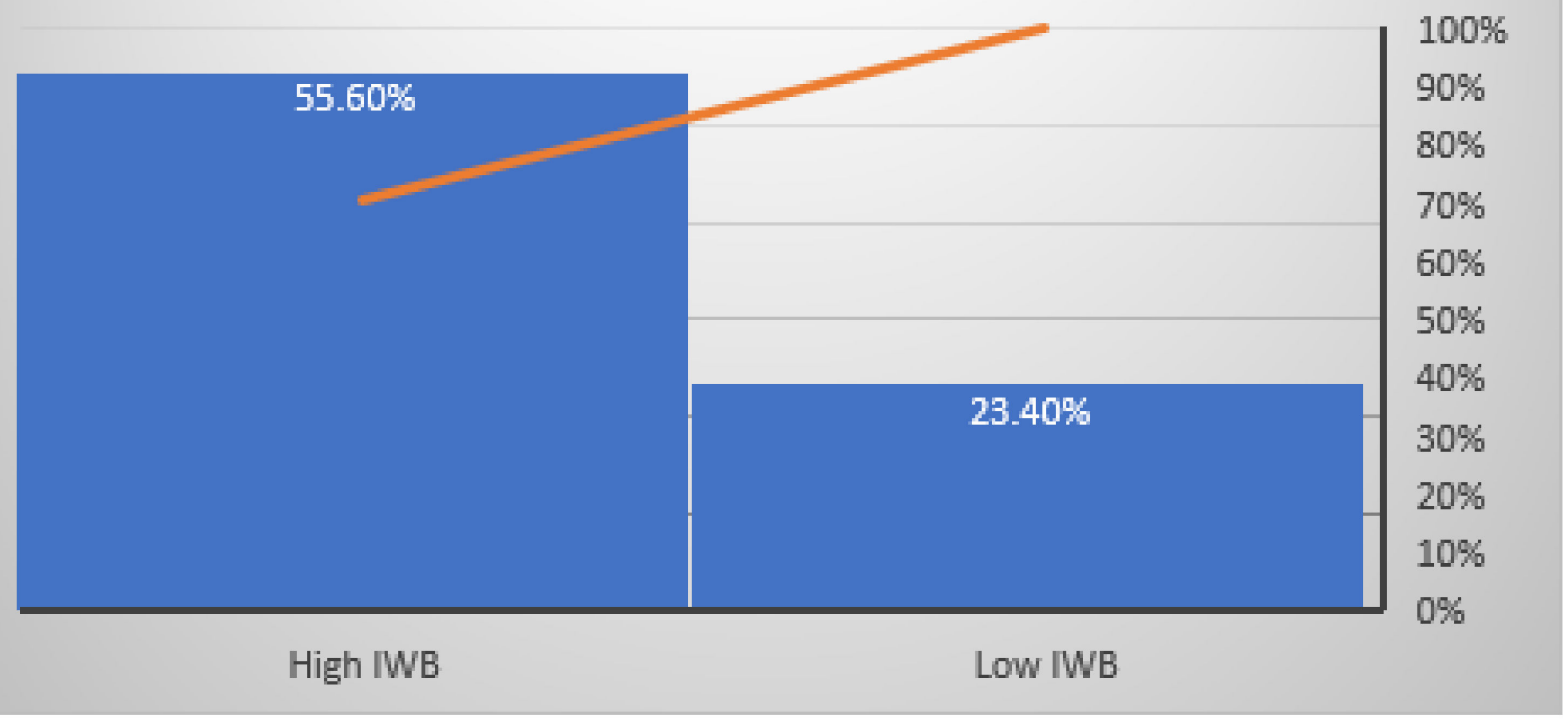

Figure 5. Perceived ethical leadership reduces stress and improves IWB.

Nevertheless, employees perceiving lower ethical leadership showed higher occupational stress and lower IWB (Figure 5; Table 7). Hence, considering Trait Activation Theory, we examined the moderating role of ethical leadership in impacting IWB. We also found that IWB is not predicted by the occupational stress, but ethical leadership reduces occupational stress and that leads to innovative work behaviour in such a manner that higher ethical leadership will lead employees to have higher IWB and lower occupational stress. Thus, the findings confirmed that ethical leadership has a positive relationship with IWB and reduces occupational stress, thereby supporting earlier studies in this discipline $[14,20,67]$.

The results further demonstrate that supervisors' creative personality could assist employees in actively exploring innovative solutions, ideas, and methods (Table 8). Therefore, this study supports the work of $[68,69]$. Furthermore, the findings support the work of [70-72] which that found that higher innovation demonstrated by employees having lower occupational stress.

Table 8. Responses reflecting IWB.

Yes... I believe that my manager has quite creative personality and this why I am more innovative and creative in putting up solutions.

Yeah, I think my manager is very creative himself and he encourages me to work on innovative ideas.

Oh yes, surely manager is creative person. He really likes and supports the creative methods than traditional approach

Furthermore, the findings reinforce the works of $[73,74]$ by confirming by a majority of $61.5 \%$ of participants that ethical leaders encourage employees' innovative work behaviour and reduces stress of employees (Table 9). Moreover, [75]'s findings confirmed that employees having a higher perception of their leader being ethical show higher efforts towards engaging in "creative-constructive" thoughts and behaviours. 
Table 9. Responses reflecting ethical leaders encourage IWB.

Our manager always concerns us when she is making a decision just to see if right thing is happening in right manner.

No, not always, my manager is promoting the right channel but still I am creative enough to develop unique ideas.

Well, yes, he always cares about the interest of employees and this is the reason I am so open to experimentations.

We found also that males perceive higher support from leaders in contrast to their female counterparts (58\% against $31 \%$, Figure 6; Table 10). Based on country comparisons, the Pakistani workforce perceives higher ethical leadership support in contrast to the Canadian workforce (61.3\% against $45.2 \%$, Figure 6; Table 10).

\section{PERCEIVED \\ HIGHER SUPPORT OF ETHICAL LEADERSHIP}

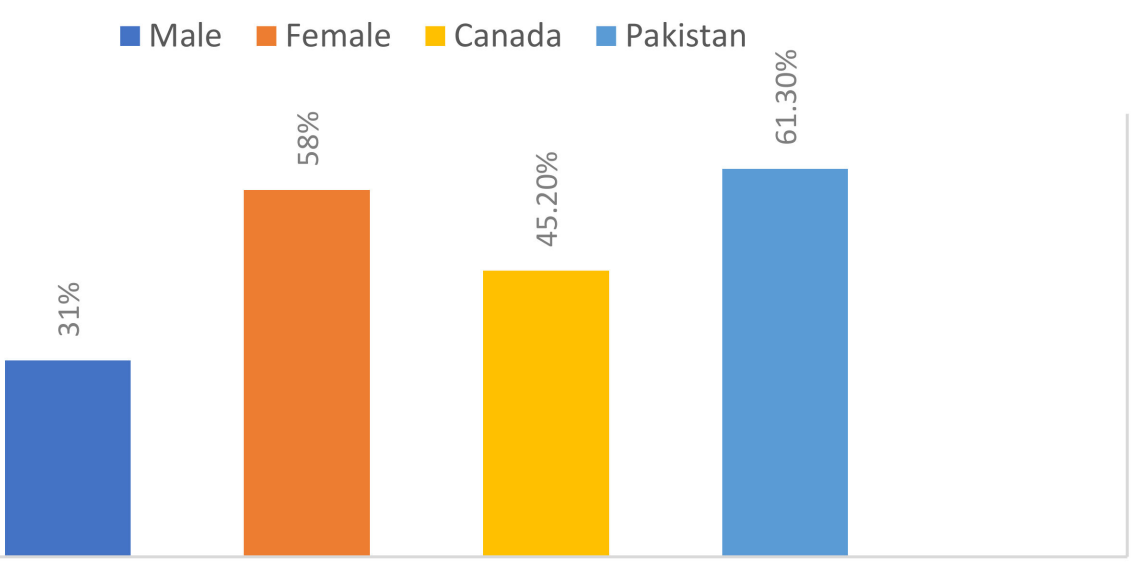

PERCEIVED HIGHER ETHICAL SUPPORT

Figure 6. Perceived ethical leadership support in different dimensions.

Table 10. Responses perceived ethical leadership support.

\begin{tabular}{c|l}
\hline $\begin{array}{c}\text { Pakistani male } \\
\text { response 1: }\end{array}$ & $\begin{array}{l}\text { Like I said before, I believe in my manager being very honest person so the trust factor } \\
\text { brings more creative elements in my thought process while I am working on tasks. }\end{array}$ \\
\hline $\begin{array}{c}\text { Canadian male } \\
\text { response 1: }\end{array}$ & I think my leader is fair person. \\
\hline $\begin{array}{c}\text { Canadian female } \\
\text { response 1: }\end{array}$ & $\begin{array}{l}\text { No, I am not right person to ask this, believe me. If his mood isn't good. We suffer for } \\
\text { no reason. This is why there is less heart at work. }\end{array}$ \\
\hline $\begin{array}{c}\text { Canadian male } \\
\text { response 2: }\end{array}$ & $\begin{array}{l}\text { Well, what can I say? I guess he is good person. He never stresses me so I work on my } \\
\text { own pace. }\end{array}$ \\
\hline $\begin{array}{c}\text { Pakistani male } \\
\text { response 3: }\end{array}$ & $\begin{array}{l}\text { Of course, I do see him very humble, nice, polite, and honest person. Yes, I enjoy } \\
\text { working under him because I trust him. He is helpful and considerate. He won't pass } \\
\text { his stress to us. }\end{array}$ \\
\hline $\begin{array}{c}\text { Pakistani female } \\
\text { response 3: }\end{array}$ & $\begin{array}{l}\text { Yes, he is humble and honest, so I like working in his team. Really have human side } \\
\text { towards his workforce. }\end{array}$ \\
\hline
\end{tabular}

The findings showed that overall, 63\% employees confirmed that ethical leaders, through their open communication and dialogue, enable employees to pursue personal 
initiatives and reduce their anxiety (Table 11). Hence, our findings confirmed similar arguments adduced by [37].

Table 11. Responses reflecting open communication impact.

$\begin{array}{r}\text { Manager is always communicating with us. He listens to us. We can share our problems and he } \\ \text { understand our stress, our problems. } \\ \text { Yes, she is very balanced person. Genuinely professional with ability discuss with all before } \\ \text { finalising anything. } \\ \hline \text { I do not remember he has ever imposed anything on us. He has charming personality and really cares for us. }\end{array}$

Another notable finding is that there was no conclusive evidence established in both cross-cultural management contexts regarding the ethical leader's anticipation for "not punishing employees for their mistakes", as only limited respondents (32\% against $11.5 \%$ ) agreed to this being a characteristic of ethical leadership (Table 12). Hence, this study differs from the work of [39].

Table 12. Responses reflecting ethical leaders do not anticipate punishments.

\begin{tabular}{c|l}
\hline Pakistani male employee: & $\begin{array}{l}\text { I cannot say much but sometimes she does question my approach when I } \\
\text { make mistakes. }\end{array}$ \\
\hline Canadian male employee: & $\begin{array}{l}\text { Although, my manager is fair but if I am doing something incorrect, he } \\
\text { takes strict notice. }\end{array}$ \\
\hline Pakistani female employee: & No, he does not punish anyone. He is very mature person. \\
\hline Canadian female employee: & Sometimes, my manager does. \\
\hline
\end{tabular}

Majority of the participants in both countries (61\% against $17.2 \%)$ confirmed that innovative solutions result from risk-taking behaviour and confident employees challenge the "status quo" (Figure 7). Males scored higher in challenging "status quo" in contrast to females $(62.3 \%$ against $19.8 \%)$, but there is no conclusive evidence of a difference of opinion in challenging the "status quo" from both countries. The majority of study participants from both countries confirmed that risk-taking behaviour often leads to deliver desired results when there is support from ethical leadership. In other words, IWB is significantly influenced by ethical leadership support. However, the risk-taking behaviour delivering desired results is a finding that contradicts the argument of $[36,76]$.

In terms of gender, in both cross-cultural country contexts, males scored higher than females in stating that risk-taking behaviour often leads to delivering desired results ( $54 \%$ against $23.2 \%$; Table 13, Figure 8 ).

However, the Pakistani workforce scored higher than the Canadian workforce $(58.6 \%$ against 27.2\%, Table 14; Figure 8).

One of the invaluable assets of the organisations is their workforce as they play vital role in the organization's success $[11,77,78]$. Thus, a lower level of occupational stress among employees enables them to address new challenges and sacrifice personal goals for organisational interests. Therefore, ethical leadership support is effective in addressing the needs of the organisation and sustaining human capital. Additionally, a large number of studies have confirmed that supportive supervision promotes risk-taking behaviour and therefore, employees show higher IWB in the workplace [79-81].

The extant literature has also found that males have higher risk-taking behaviour than females, irrespective of the supervisory support ( $58.6 \%$ against $27.2 \%$, Table 15 ). Furthermore, present findings support the work of [54] that leaders' ethical duty includes fostering employees' risk-taking in order to encourage them to be more creative. Moreover, the analysis of the interview transcripts also showed that systematic training programmes should be introduced to reduce stress and educate ethical leadership to support employees demonstrating IWB. Therefore, this study supports, to a large extent, the findings of $[82,83]$. 


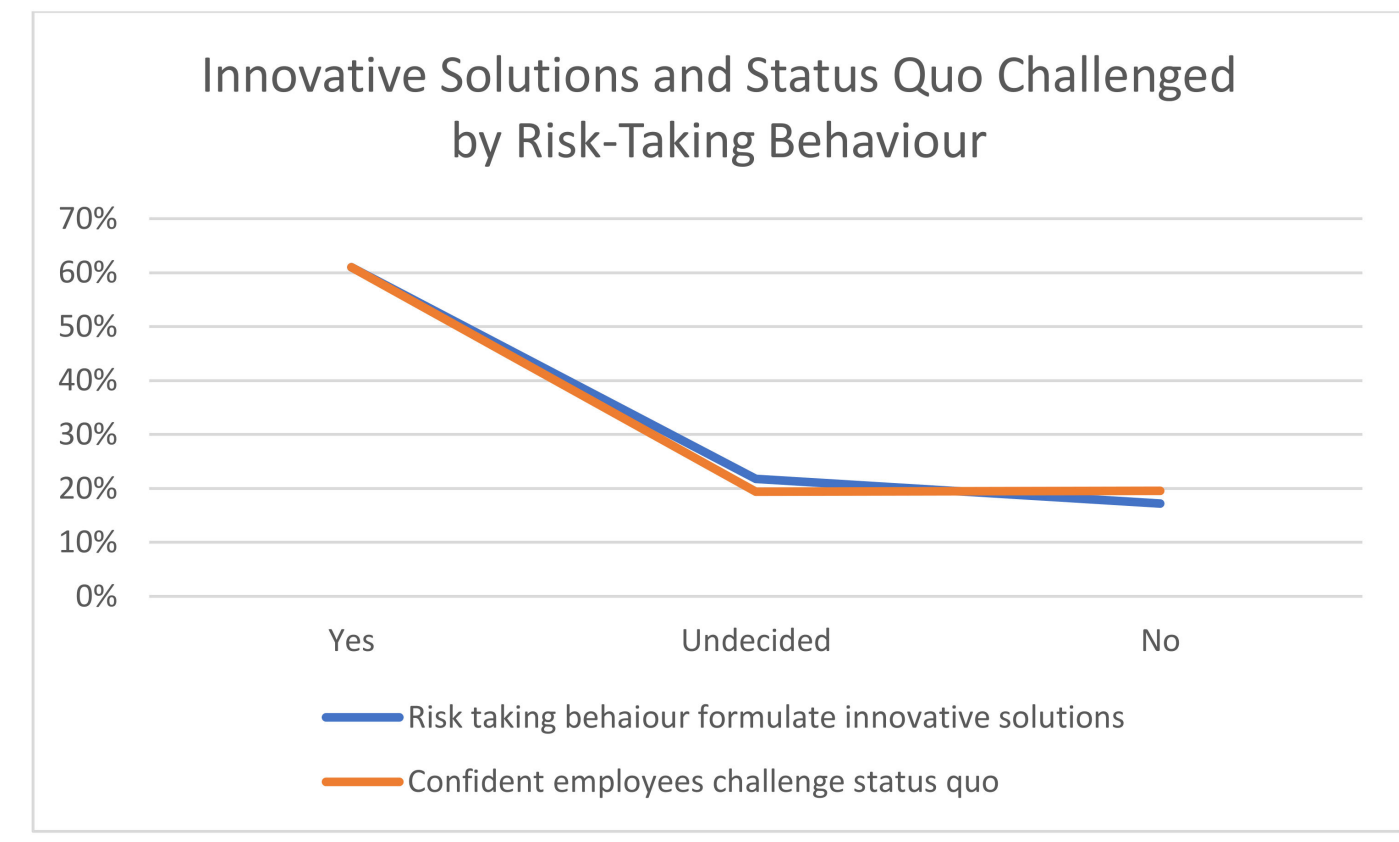

(a)

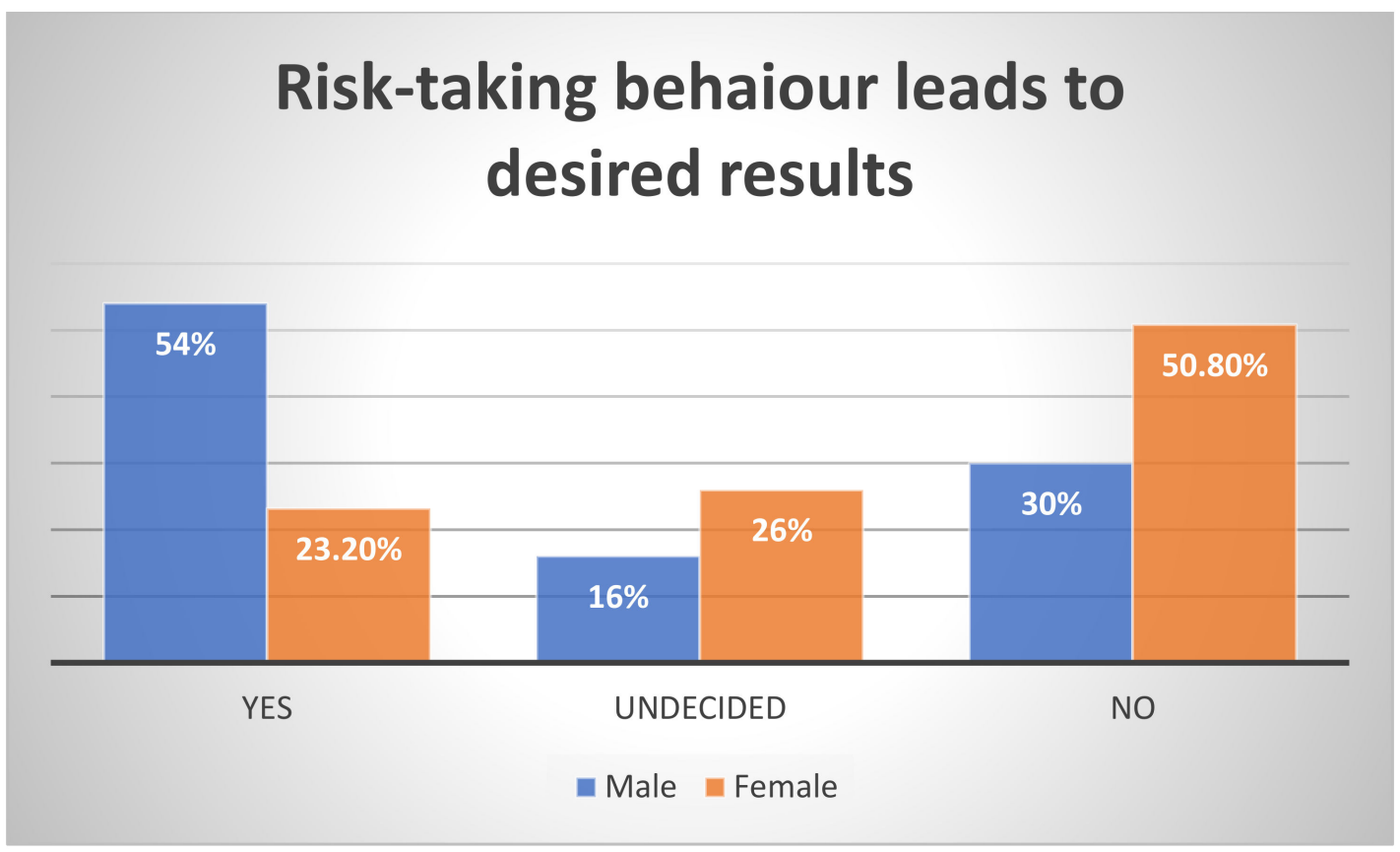

(b)

Figure 7. (a) Risk-taking behaviour improves innovative solutions and challenges the status quo. (b) Contrasting gender responding to risk-taking behaviour leads to desired results.

Table 13. Responses reflecting risk-taking behaviour leads to desired results.

\begin{tabular}{c|l}
\hline Pakistani male 1: & Yes, more chances you will take, more you are likely to get results \\
\hline Canadian male 1: & Risk is everywhere, If you do not take initiative, less likely you will get good results. \\
\hline Pakistani female 1: & No, I do not thing that you have to be daring and risk-taking to get things done. \\
\hline Canadian female 2: & $\begin{array}{l}\text { Not always, It is not necessary that if I do not have risk-taking behaviour then I will } \\
\text { not get desired results. }\end{array}$ \\
\hline
\end{tabular}




\section{Risk-taking behaviour leads to desired results (Country context)}

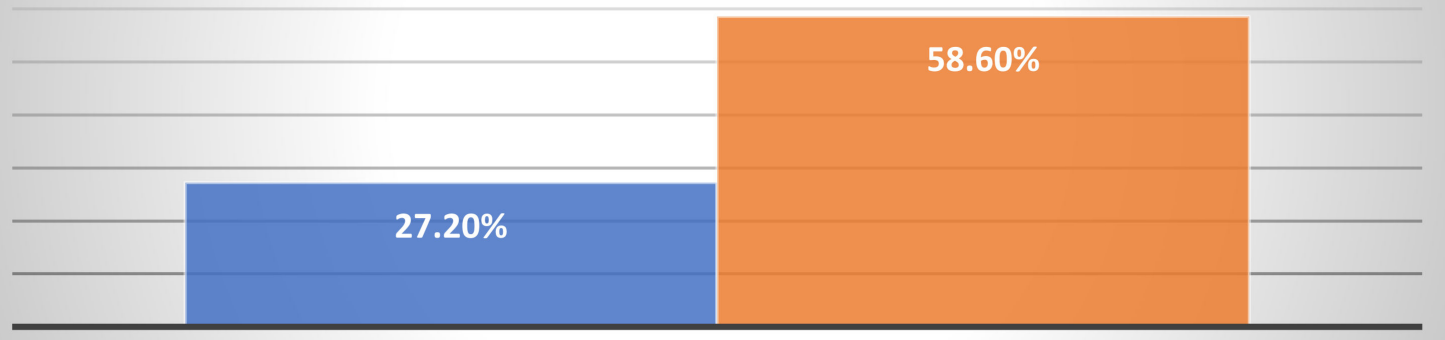

1

- Canada - Pakistan

Figure 8. Contrasting economies responding to risk-taking behaviour leads to desired results.

Table 14. Responses reflecting risk-taking behaviour leads to desired results (country context).

\begin{tabular}{c|l}
\hline Pakistani male: & $\begin{array}{l}\text { Yes, I feel you have to be daring to try new things. Remember nothing great ever } \\
\text { happen unless you try it and believe me, it pays off. }\end{array}$ \\
\hline Pakistani female: & Sometimes you have to take risk to make things happen for good. \\
\hline Canadian female: & Results could be even obtained without being ultra-aggressive. \\
\hline Canadian male: & No, without risk still one can manage to get desired outcome. \\
\hline
\end{tabular}

Table 15. Responses reflecting risk-taking behaviour irrespective of supervisory support (gender perspective).

\begin{tabular}{|c|c|}
\hline Males 1: & $\begin{array}{l}\text { Not matter if I have any support from the manager, I will still take my risks to be } \\
\text { more dynamic. }\end{array}$ \\
\hline Males 2: & $\begin{array}{l}\text { Yes, I will take my chances, if support comes from others good but if not, I will still do it } \\
\text { my way. }\end{array}$ \\
\hline Females 1: & Only if I have support \\
\hline Females 2: & $\begin{array}{l}\text { I cannot say but why do you need to take risk, if it is not required so support is altogether } \\
\text { another thing. }\end{array}$ \\
\hline
\end{tabular}

\section{Conclusions}

The ethical behaviour of organisational leaders plays a significant role in promoting innovative ideas, work behaviour, and solutions among employees having an "openness to experience" trait. It is evident that employees' occupational stress negatively affects their IWB, and IWB is significantly higher due to the moderate role of ethical leadership. In addition, it is evident that males, in contrast to their female counterparts, have a higher tendency to take risks and demonstrate innovative work behaviour. Employees perceiving their leaders to be ethical demonstrate higher creative-constructive thinking. Interestingly, males received higher support from their leaders in both country settings. This could be largely credited to the existing norms and cultures prevailing inside the organisations. Again, it is evident that relatively higher ethical leadership support is given to the Pakistani workforce in contrast to the Canadian workforce compared in this study. The Pakistani workforce scored higher than the Canadian workforce in risk-taking and IWB. This could largely be accredited to the age factor, as the Pakistani workforce is relatively younger in comparison to the Canadian workforce. Interestingly, the ethical leadership's 
anticipation to not punish workers for their mistakes is not a key characteristic to enhance innovative behaviour. In fact, it is not even viewed by employees as a supportive effort of leaders in increasing innovative behaviour. Stress from the manager can affect IWB, while leaders who are able to handle stress of employees can bring the best out of employees. Moreover, males in contrast to females have a higher tendency to challenge the "status quo" in the organisations. Moreover, it is evident that risk-taking behaviour often leads to desired results, and in this regard, males scored higher than females. Furthermore, the Pakistani workforce demonstrated higher risk-taking behaviour and agreed that this leads to attaining desired results. The Canadian workforce scored lower; however, this study found that although ethical leaders' support is vital in fostering innovative behaviour, males are more often risk takers while females are generally risk-averse, irrespective of the ethical leadership support that is provided or available. Stress is inevitable in the workplace, and it can negatively affect the creativity of employees. Ethical leaders are vital in the reduction of stress and creating an atmosphere that promotes innovative workplace behaviour.

This research paper has a limitation of understudying "openness to experience", which is one of the personality traits interlinked with Trait Activation Theory. Our focus was more on the innovative work behaviour and occupational stress while ignoring the openness to experience. Hence, we recommend that future studies incorporate it so there is higher generalizability and in-depth understanding of Trait Activation Theory.

Furthermore, the research design could be improved by including more cross-cultural studies. This study focused on covering multiple dimensions, and it came at the expense of a moderate research design. It would be interesting to see the inclusion of a cross-cultural study framework further incorporated to examine the variables of interest.

This study is qualitative in nature, while previously, researchers focused on quantitative aspects. Still, a mixed methodology is missing that could offer a holistic view of the research phenomenon. Using the positivistic approach vs. grounded theory for just qualitative studies could perhaps improve research designs.

\section{Theoretical and Practical Implications}

One of the critical contributions of this research to the literature is insight supporting the consideration of ethical leadership as a moderating variable to understand the relationship between IWB and occupational stress as an important addition to the extant literature. Prior to this study, there was no conclusive research that considered the role of ethical leadership in dealing with stress and IWB simultaneously. For this reason, we provide a new insight through discussing leadership to explore the concepts of IWB and occupational stress within one construct. Since previous research extensively adopts quantitative methods while neglecting the most prominent work feature (occupational stress), we focused on the qualitative aspect of the phenomenon by including occupational stress. This provided an explorative aspect instead of testing statistical results. We further critically evaluated the value-based leadership theories and connected them with the concept of occupational stress, which is a new theoretical stance previously not found in the existing literature.

This study also offers practical implications for managers/supervisors/leaders within the organisational setting to enhance employees' innovative work behaviour to manage the dynamic challenges of dealing with occupational stress. Hence, this paper reinforces the significant implications of ethical values (value-based leadership) in the workplace because it promotes the achievement of organisational goals while facilitating a positive management of employee stress. Leaders and workers are both part of society; therefore, ethical vision, mission, and innovative work behaviour is an individual as well as a collective responsibility to improve the overall image of organisations and societies. This paper offers deeper insight that can inform guidance to organisations to address and mitigate the challenges of the dynamic business environment through the reduction of occupational stress (such as by offering stress management programmes, workshops, ventilation sessions) so that innovative work behaviour of employees can be enhanced. 
Author Contributions: Conceptualization, A.u.H., and F.A.Y.; methodology, A.u.H.; Analysis, F.A.Y.; investigation, F.A.Y., and A.u.H.; writing—original draft preparation, A.u.H. and F.A.Y.; writingreview and editing, F.A.Y., and A.u.H., supervision, F.A.Y. Revising and addressing comments, A.u.H. All authors have read and agreed to the published version of the manuscript.

Funding: This research received no external funding.

Institutional Review Board Statement: The study was conducted according to the guidelines of Yorkville University and approved by the YU Board of Ethics Committee.

Informed Consent Statement: Informed consent was obtained from all participants.

Data Availability Statement: No applicable.

Conflicts of Interest: The authors declare no conflict of interest.

\section{References}

1. Crossan, M.M.; Apaydin, M. A Multi-Dimensional Framework of Organizational Cultures: A Comparative Analysis of German and US Perspectives. Bus. Ethics Eur. Rev. 2010, 18, 127-144.

2. Yuan, F.; Woodman, R.W. Innovative Behavior in the Workplace: The Role of Performance and Image Outcome Expectations. Acad. Manag. J. 2010, 53, 323-342. [CrossRef]

3. Scott, S.G.; Bruce, R.A. Determinants of Innovative Behavior: A Path Model of Individual Innovation in the Workplace. Acad. Manag. J. 1994, 37, 580-607.

4. Janssen, O.; van de Vliert, E.; West, M. The bright and dark sides of individual and group innovation: A Special Issue introduction. J. Organ. Behav. 2004, 25, 129-145. [CrossRef]

5. Carmeli, A.; Spreitzer, G.M. Trust, connectivity, and thriving: Implications for innovative behaviors at work. J. Creat. Behav. 2009, 43, 169-191. [CrossRef]

6. Young, L.D. How to promote occupational stress innovative behavior at work? The role of justice and support within organizations. J. Creat. Behav. 2012, 46, 220-243.

7. Leonard, D.; Swap, W. When Sparks Fly: Harnessing the Power of Group Creativity. Camb. Harv. Bus. Rev. 2005. Available online: https: / / www.hbs.edu/faculty/Pages/item.aspx?num=19603 (accessed on 10 February 2021).

8. Hammond, M.M.; Neff, N.L.; Farr, J.L.; Schwall, A.R.; Zhao, X. Predictors of Individual Level Innovation at Work: A Meta-analysis. Psyc. Aesth. Creat. Arts 2011, 5, 90-105. [CrossRef]

9. Javed, B.; Naqvi, S.M.M.R.; Khan, A.K.; Arjoon, S.; Tayyeb, H.H. Impact of inclusive leadership on innovative work behavior: The role of psychological safety. J. Manag. Organ. 2019, 25, 117-136. [CrossRef]

10. Cicei, C.C. Occupational stress and organizational commitment in Romanian public organizations. Proc. Soc. Behav. Sci. 2012, 33, 1077-1081. [CrossRef]

11. Haque, A.U.; Aston, J. A Relationship between Occupational Stress and Organizational Commitment of I.T Sector's Employees in Contrasting Economies. Pol. J. Manag. Stud. 2016, 14, 95-105.

12. Haque, A.U.; Aston, J.; Kozlovski, E. The Impact of Stressors on Organizational Commitment of Managerial and Non-Managerial Personnel in Contrasting Economies. Int. J. Bus. 2018, 23, 166-182.

13. Haque, A.U.; Oino, I. Managerial challenges for software houses related to work, worker and workplace: Stress reduction and sustenance of human capital. Pol. J. Manag. Stud. 2019, 19, 170-189. [CrossRef]

14. Haque, A.U.; Aston, J.; Kozlovski, E.; Caha, Z. Role of External CSR and Social Support Programme for Sustaining Human Capital in Contrasting Economies. Pol. J. Manag. Stud. 2020, 22, 147-168.

15. Kumasey, S.A.; Delle, E.; Ofei, B.S. Occupational Stress and Organisational Commitment: Does Sex and Managerial Status Matter? Int. J. Bus. Soc. Res. 2014, 4, 173-182.

16. Marshall, C.; Rossman, G.B. Designing Qualitative Research, 4th ed.; Sage Publication: Newbury Park, CA, USA, 2006; p. 262, ISBN 9781412924894.

17. Faizan, R.; Haque, A.U.; Cockrill, A.; Aston, J. Females at Strategic Level Affecting Logistics Firms' Competitiveness: Qualitative Comparative Analysis of Contrasting Gender in Pakistan and Canada. Forum Sci. Oeconomia 2019, 7, 57-71.

18. Hurt, H.T.; Joseph, K.; Cook, C.D. Scales for the Measurement of Innovativeness. Hum. Comm. Res. 1977, 4, 58-65. [CrossRef]

19. Zhou, J.; George, J.M. When Job Dissatisfaction leads to Creativity: Encouraging the Expression of Voice. Acad. Manag. J. 2001, 44, 682-696.

20. Patterson, F.; Kerrin, M.; Gatto-Roissard, G. Characteristics and Behaviours of Innovative People in Organisations. In Literature Review; NESTA Policy Research Unit: London, UK, 2009; Available online: http:/ /www.nesta.org.uk/publications/characteristicsand-behaviours-innovative-people-organisations (accessed on 10 February 2021).

21. Hsieh, H.L.; Hsieh, J.R.; Wang, I.L. Linking personality and innovation: The role of knowledge management. World Trans. Eng. Technol. Educ. 2011, 9, 38-44.

22. Javed, B.; Bashir, S.; Rawwas, M.Y.; Arjoon, S. Islamic Work Ethic, innovative work behaviour, and adaptive performance: The mediating mechanism and an interacting effect. Curr. Iss. Tour. 2017, 20, 647-663. [CrossRef] 
23. Rousseau, D.M.; Fried, Y. Location, location, location: Contextualizing organizational research. J. Organ. Behav. 2001, $22,1-13$. [CrossRef]

24. Griffin, M.A. Specifying organizational contexts: Systematic links between contexts and processes in organizational behavior. J. Organ. Behav. 2007, 28, 859-863. [CrossRef]

25. Kenrick, D.T.; Funder, D.C. Profiting from controversy: Lessons from the person-situation debate. Am. Psychol. 1988, 43, 23. [CrossRef]

26. Tett, R.P.; Guterman, H.A. Situation trait relevance, trait expression, and cross-situational consistency: Testing a principle of trait activation. J. Res. Personal. 2000, 34, 397-423. [CrossRef]

27. Blickle, G.; Meurs, J.A.; Wihler, A.; Ewen, C.; Plies, A.; Günther, S. The interactive effects of conscientiousness, openness to experience, and political skill on job performance in complex jobs: The importance of context. J. Organ. Behav. 2013, 34, 1145-1164. [CrossRef]

28. Pieterse, A.N.; Van Knippenberg, D.; Schippers, M.; Stam, D. Transformational and transactional leadership and innovative behavior: The moderating role of psychological empowerment. J. Organ. Behav. 2010, 31, 609-623. [CrossRef]

29. Weng, R.H.; Huang, C.Y.; Chen, L.M.; Chang, L.Y. Exploring the impact of transformational leadership on nurse innovation behaviour: A cross-sectional study. J. Nur. Manag. 2015, 23, 427-439. [CrossRef]

30. De Jong, J.; Den Hartog, D. Measuring innovative work behaviour. Creat. Innov. Manag. 2010, 19, 23-36. [CrossRef]

31. Gong, Y.; Huang, J.C.; Farh, J.L. Employee learning orientation, transformational leadership, and employee creativity: The mediating role of employee creative self-efficacy. Acad. Manag. J. 2009, 52, 765-778. [CrossRef]

32. Brown, M.E.; Treviño, L.K.; Harrison, D.A. Ethical Leadership: A Social Learning Perspective for Construct Development and Testing. Organ. Behav. Hum. Decis. Proc. 2005, 97, 117-134. [CrossRef]

33. Piccolo, R.F.; Greenbaum, R.; Hartog, D.N.D.; Folger, R. The relationship between ethical leadership and core job characteristics. J. Organ. Behav. 2010, 31, 259-278. [CrossRef]

34. Treviño, L.K.; Brown, M.; Hartman, L.P. A qualitative investigation of perceived executive ethical leadership: Perceptions from inside and outside the executive suite. Hum. Relat. 2003, 56, 5-37. [CrossRef]

35. Martins, E.; Terblanche, F. Building organizational culture that stimulates creativity and Innovation. Eur. J. Innov. Manag. 2003, 6, 64-74. [CrossRef]

36. Tett, R.P.; Burnett, D.D. A Personality Trait-based Interactionist Model of Job Performance. J. Appl. Psychol. 2003, 88, 500. [CrossRef] [PubMed]

37. Tu, Y.; Lu, X. Do ethical leaders give followers the confidence to go the extra mile? The moderating role of intrinsic motivation. J. Bus. Ethics 2016, 135, 129-144. [CrossRef]

38. Brown, M.E.; Treviño, L.K. Ethical Leadership: A Review and Future Directions. Lead. Q. 2006, 17, 595-616. [CrossRef]

39. De Hoogh, A.H.; Den Hartog, D.N. Ethical and Despotic Leadership, Relationships with Leader's Social Responsibility, Top Management Team Effectiveness and Subordinates' Optimism: A Multi-Method Study. Lead. Q. 2008, 19, 297-311. [CrossRef]

40. Martin, G.S.; Resick, C.J.; Keating, M.A.; Dickson, M.W. Ethical leadership across cultures: A comparative analysis of German and US perspectives. Bus. Ethics Eur. Rev. 2009, 18, 127-144. [CrossRef]

41. Janssen, O. Job Demands, Perceptions of Effort-reward Fairness and Innovative Work Behaviour. J. Occup. Organ. Psychol. 2000, 73, 287-302. [CrossRef]

42. Faizan, R.; Zehra, N. Quality Work-Life as predictor to Organizational Commitment under contrasting Leadership Styles: I.T Responses from Pakistan's private software houses. Glob. J. Manag. Admin. 2016, 16, 9-23.

43. Zehra, N.; Faizan, R. The Impact of Occupational Stress on Employees at Project Based Organizations (PBOs) in Pakistan, International. J. Appl. Bus. Manag. Stud. 2017, 2,1-9.

44. Haque, A.U.; Sher, A.; Urbański, M. Is the role of Authentic Leadership Effective in Managing Occupational Stress and Psychological Capital? Forum Sci. Oeconomia 2020, 8, 59-77.

45. Baer, M.; Oldham, G.R. The Curvilinear Relation between Experienced Creative Time Pressure and Creativity: Moderating Effects of Openness to Experience and Support for Creativity. J. Appl. Psychol. 2006, 91, 963-970. [CrossRef] [PubMed]

46. Balka, K.; Raasch, C.; Herstatt, C. The Effect of Selective Openness on Value Creation in User Innovation Communities. J. Prod. Innov. Manag. 2014, 31, 392-407. [CrossRef]

47. McCrae, R.R.; Costa, P.T., Jr. Validation of the Five-factor Model of Personality across Instruments and Observers. J. Personal. Soc. Psychol. 1987, 52, 81-90. [CrossRef]

48. McCrae, R.R.; Costa, P.T., Jr. Personality trait structure as a human universal. Am. Psychol. 1997, 52, 509. [CrossRef]

49. Henry, J. Creativity and Perception in Management; Sage: London, UK, 2001.

50. Kisfalvi, V.; Pitcher, P. Doing what feels Right: The Influence of CEO Character and Leadership: The Mediating Role of Employee Voice and Psychological Ownership. J. Bus. Ethics 2003, 107, 21-34.

51. Grint, K. Leadership: Limits and Possibilities; Palgrave Macmillan: Basingstoke, UK, 2005.

52. Baucus, M.S.; Norton, W.I., Jr.; Baucus, D.A.; Human, S.E. Fostering creativity and innovation without encouraging unethical behavior. J. Bus. Ethics 2008, 81, 97-115. [CrossRef]

53. Walumbwa, F.O.; Schaubroeck, J. Leader personality traits and employee voice behavior: Mediating roles of ethical leadership and work group psychological safety. J. Appl. Psychol. 2009, 94, 1275. [CrossRef] 
54. Demirtas, O.; Akdogan, A.A. The Effect of Ethical Leadership Behavior on Ethical Climate, Turnover Intention, and Affective Commitment. J. Bus. Ethics 2015, 130, 59-67. [CrossRef]

55. Côté, S.; Moskowitz, D.S. On the dynamic covariation between interpersonal behavior and affect: Prediction from neuroticism, extraversion, and agreeableness. J. Personal. Soc. Psychol. 1998, 75, 1032. [CrossRef]

56. Haque, A.; Fernando, M.; Caputi, P. How is responsible leadership related to the three-component model of organisational commitment? Int. J. Prod. Perform. Manag. 2020. [CrossRef]

57. Javed, B.; Khan, A.K.; Arjoon, S.; Mashkoor, M.; Haque, A.U. Openness to experience, ethical leadership, and innovative work behavior. J. Creat. Behav. 2018, 54, 211-223. [CrossRef]

58. Anser, M.K.; Ali, M.; Usman, M.; Rana, M.L.T.; Yousaf, Z. Ethical leadership and knowledge hiding: An intervening and interactional analysis. Serv. Ind. J. 2021, 41, 307-329. [CrossRef]

59. Saleem, M.; Qadeer, F.; Mahmood, F.; Ariza-Montes, A.; Han, H. Ethical leadership and employee green behavior: A multilevel moderated mediation analysis. Sustainability 2020, 12, 3314. [CrossRef]

60. Usmanova, K.; Wang, D.; Younas, A. Leader's strategy to encourage employee's innovative work behavior in multicultural workplace: Do supportive colleagues matter? Chin. Manag. Stud. 2021. [CrossRef]

61. Haque, A. Strategic HRM and organisational performance: Does turnover intention matter? Int. J. Organ. Anal. 2020, 29 , 656-681. [CrossRef]

62. Hofstede, G.; Hofstede, G.J.; Minkov, M. Cultures and Organizations: Software of the Mind; McGraw-Hill: New York, NY, USA, 2005; Volume 2.

63. Langrial, S.; Kashif, M.; Ehsan, U. Exploring attitudes of Pakistani and Canadian children towards television advertisements: A cross-cultural comparative analysis. Asian Pac. J. Manag. Res. Innov. 2014, 10, 191-201. [CrossRef]

64. Creswell, J.W. Research Design: Qualitative, Quantitative, and Mixed Methods Approaches, 4th ed.; SAGE: London, UK, 2013.

65. Raja, U.; Johns, G. The joint effects of personality and job scope on in-role performance, citizenship behaviors, and creativity. Hum. Relat. 2010, 63, 981-1005. [CrossRef]

66. Gilmore, P.L.; Hu, X.; Wei, F.; Tetrick, L.E.; Zaccaro, S.J. Positive affectivity neutralizes transformational leadership's influence on creative performance and organizational citizenship behaviors. J. Organ. Behav. 2013, 34, 1061-1075. [CrossRef]

67. Yesil, S.; Sozbilir, F. An empirical investigation into the impact of personality on individual innovation behaviour in the workplace. Proc. Soc. Behav. Sci. 2013, 81, 540-551. [CrossRef]

68. Gough, H.G. A Creative Personality Scale for the Adjective Check List. J. Personal. Soc. Psychol. 1979, 37, 1398. [CrossRef]

69. Amabile, T. Creativity in Context: Update to The Social Psychology of Creativity; Westview Press: Boulder, CO, USA, 1996.

70. Patterson, F. Great Minds don't think alike? Person-level Predictors of Innovation at Work. Int. Rev. Ind. Organ. Psychol. 2002, 7, 115-144.

71. Harrison, M.M.; Neff, N.L.; Schwall, A.R.; Zhao, X. A meta-analytic investigation of individual creativity and innovation. In Proceedings of the 21st Annual Conference for the Society for Industrial and Organizational Psychology, Dallas, TX, USA, 6 May 2006.

72. Nga, J.K.H.; Shamuganathan, G. The Influence of Personality Traits and Demographic Factors on Social Entrepreneurship Start-up Intentions. J. Bus. Ethics 2010, 95, 259-282.

73. Resick, C.J.; Hargis, M.B.; Shao, P.; Dust, S.B. Ethical Leadership, Moral Equity Judgments, and Discretionary Workplace Behavior. Hum. Relat. 2013, 66, 951-972. [CrossRef]

74. Newman, A.; Kiazad, K.; Miao, Q.; Cooper, B. Examining the Cognitive and Affective Trust-based Mechanisms underlying the Relationship between Ethical Leadership and Organisational Citizenship: A Case of the Head leading the Heart? J. Bus. Ethics 2014, 123, 113-123. [CrossRef]

75. Mumford, M.D. Managing creative people: Strategies and tactics for innovation. Hum. Res. Manag. Rev. 2000, 10, 313-351. [CrossRef]

76. Lievens, F.; De Koster, L.; Schollaert, E. Current theory and practice of assessment centres: The importance of trait activation. Oxf. Handb. Pers. Psychol. 2008, 215-233. [CrossRef]

77. Nehmeh, R. What is Organizational Commitment, Why Should Managers Want It in Their Workforce and Is there Any Cost Effective Way to Secure It? Swiss Management Centre (SMC): Zug, Switzerland, 2009.

78. Haque, A.U.; Yamoah, F. Gender Employment Longevity: I.T Staff Response to Organizational Support in Pakistan. Int. J. Acad. Res. Bus. Soc. Sci. 2014, 4, 324-347. [CrossRef]

79. Deci, E.L.; Ryan, R.M. The support of autonomy and the control of behavior. J. Per. Soc. Psychol. 1987, 53, 1024. [CrossRef]

80. Deci, E.L.; Connell, J.P.; Ryan, R.M. Self Determination in a Work Organization. J. Appl. Psychol. 1989, 74, 580-590. [CrossRef]

81. Oldham, G.R.; Cumming, A. Employee Creativity: Personal and Contextual Factors at Orchestrating Expertise and Relationships. Lead. Q. 1996, 13, 705-750.

82. Poff, D.C. Ethical Leadership and Global Citizenship: Considerations for a Just and Sustainable Future. J. Bus. Ethics 2010, 93, 9-14. [CrossRef]

83. Swailes, S. The Ethics of Talent Management. Bus. Ethic A Eur. Rev. 2013, 22, 32-46. [CrossRef] 